\title{
Teaching Problems and the Problems of Teaching
}


This page intentionally left blank 


\title{
Teaching
}

\section{Problems}

\author{
and the
}

\section{Problems of Teaching}

Magdalene Lampert 
Copyright $\odot 2001$ by Yale University

All rights reserved.

This book may not be reproduced, in whole or in part, including illustrations, in any form (beyond that copying permitted by Sections 107 and 108 of the U.S. Copyright Law and except by reviewers for the public press), without written permission from the publishers.

Designed and typeset in Adobe Minion by Mary Cronin.

Printed in the United States of America.

Library of Congress Cataloging-in-Publication Data

Lampert, Magdalene.

Teaching problems and the problems of teaching / Magdalene Lampert. p. cm.

Includes bibliographical references.

ISBN 978-0-300-08973-8 (cloth.: alk. paper)

ISBN 978-0-300-09947-8 (pbk: alk. paper)

1. Mathematics - Study and teaching (Elementary) - United States - Case studies. 2. Effective teaching-United States-Case studies. I. Title

QA135.6.L36 2001

$372.7-\mathrm{dc} 21$

2001002322

A catalogue record for this book is available from the British Library.

The paper in this book meets the guidelines for permanence and durability of the Committee on Production Guidelines for Book Longevity of the Council on Library Resources.

109876 
This book is dedicated to the Lampert Family, whose tradition of adventure I hope it continues 
This page intentionally left blank 